\title{
The effect of critical success factors of quality management to excellence in Iraqi Universities
}

\author{
Ahmed Hani Mohammed \\ Administration and Economic College, University of Mosul, Mosul, Iraq \\ Che Azlan Taib \\ School of Technology Management and Logistics, Universiti Utara Malaysia
}

\begin{abstract}
Key words
Critical Success Factors (CSFs), Iraqi Universities, Excellence.
\end{abstract}

\begin{abstract}
The purpose of this paper to measuring the effect of critical success factors to excellence in Iraqi universities. The empirical data was drawn from the head of departments in six Iraqi universities, the number of respondents was 174 . The research model was tested by using the partial least square structural equation modeling (PLS-SEM) technique. The findings of the empirical study revealed that critical success factors have a positive effect on excellence. Theoretically, the practices of critical success factors have contributed to understanding the different roles in excellence in Iraqi universities. From another side, this study shows practical implications, where increasing the attention of the factors to help the head of department in Iraqi universities to improve the performance.
\end{abstract}

Corresponding author: Ahmed Hani Mohammed

Email addresses for the corresponding author: ahmed_hani@uomosul.edu.iq

First submission received: $22^{\text {nd }}$ April 2018

Revised submission received: $19^{\text {th }}$ July 2018

Accepted: 21 ${ }^{\text {st }}$ August 2018

\section{Introduction}

The higher education sector is recognized globally as being a crucial service sector in meeting students' needs and requirements. This is supported by the introduction of appropriate factors being employed to excellence in higher education (HE). Several studies have shown that enhancing the education will lead to increased satisfaction among students in supporting their entry towards realizing increased opportunities for employment and obtaining a higher life standard (Hussain \& Birol, 2011; Policy \& Education, 2000). As a part of the continued academic study of improvement programs, researchers have recently explored critical success factors (CSFs) (Antony, Leung, Knowles, \& Gosh, 2002; Chan, Lau, Ip, Chan, \& Kong, 2005; Farris, Van Aken, Doolen, \& Worley, 2009; Glover, Farris, Van Aken, \& Doolen, 2011; Shieh, Wu, \& Huang, 2010; Stock, McFadden, \& Gowen, 2007). Much effort is needed in developing a model for excellence since many CSFs should be considered for it (Ahmad, Francis, \& Zairi, 2007), whether for public universities or for private universities. CSFs considered as an aid to universities to make their action plan and successful system (Yeoh \& Koronios, 2010). According to the framework developed by the Iraqi Higher Education regarding quality programs, the Ministry of Higher Education and Scientific Research in Iraqi (MOHESR) aimed to extend the quality among the universities in Iraq. Both entities also aimed to revise the plans laid out for excellence (UNESCO, 2013). Therefore, an investigation of CSFs for excellence implementation in Iraqi universities was worthwhile to carry out.

\section{Background}

The need for excellence, especially in light of the intense competition among the developed countries, requires developed and integrated systems in the quality measure. To meet the obligations terms of quality, speed, and efficiency, and by giving a specific definition expresses excellence through quality, but it is important to identify a group of CSFs to suit with university's needs of achieving a success and excellence. It stated CSFs as a concept was introduced by Daniel (1961). The purpose of examining critical success factors for improving the overall quality services, and it can be identified to 
improvement by observing the causal relationships of these critical success factors (Shieh et al., 2010). In this period a system was issued that helps universities to achieve excellence through improving critical success factors. Based on the literature review this paper has identified a total of six critical factors for quality as referrer as CSFs (Top management commitment, Human resource development, Customer focus, Management of process quality, Information \& Analysis, and Strategic planning), as shown in Table 1, and Table 2. To further understanding of the relationship between the CSFs and higher education excellence as shown in the model figure 1. For that, the hypothesis is:

H1: There is direct effects of critical success factors on higher education excellence.

Table 1: Critical Success factors in higher education

\begin{tabular}{|l|l|l|l|l|l|l|l|l|l|l|l|l|l|l|}
\hline \multicolumn{1}{|c|}{ Authors } & \multicolumn{7}{c|}{ Critical Success Factors* } \\
\hline & 1 & 2 & 3 & 4 & 5 & 6 & 7 & 8 & 9 & 10 & 11 & 12 & 13 & 14 \\
\hline (Badri et al., 2006) & & & & & & & & & & & & & & \\
\hline (Bozbura, Bayraktar, \& Tatoglu, 2011) & & & & & & & & & & & & & & \\
\hline (Islam, 2007) & & & & & & & & & & & & & & \\
\hline (Sondari, 2013) & & & & & & & & & & & & & & \\
\hline (Seth et al., 2016) & & & & & & & & & & & & & \\
\hline $\begin{array}{l}\text { (Koo, Chung, \& Ryoo, 2014; Mishra, } \\
\text { Pundir, \& Ganapathy, 2016) }\end{array}$ & & & & & & & & & & & & & & \\
\hline $\begin{array}{l}\text { (Awheda, Ab Rahman, Ramli, \& Arshad, } \\
\text { 2016; Chuang \& Yang, 2014) }\end{array}$ & & & & & & & & & & & & & & \\
\hline (Honnutagi, Sonar, \& Babu, 2011) & & & & & & & & & & & & & & \\
\hline (Talib \& Rahman, 2010) & & & & & & & & & & & & & & \\
\hline
\end{tabular}

* Note: 1. Top management commitment 2. Management of process quality 3. Customer focus 4. Information \& Analysis 5. Strategic planning 6. Human resource development 7. Vision 8. Program design 9. Organizational culture 10. Green product 11. Organizational practices 12. Technology management 13. Employee involvement \& encouragement 14. Benchmarking

Table 2: Prioritization of CSFs

\begin{tabular}{|l|l|c|c|}
\hline No. & Critical Success Factors & $\begin{array}{c}\text { Frequency of } \\
\text { Occurrence }\end{array}$ & Prioritized \\
& Rank \\
\hline 1 & Top management commitment & 11 & 1 \\
\hline 2 & Human resource development & 10 & 2 \\
\hline 3 & Customer focus & 9 & 3 \\
\hline 4 & Management of process quality & 7 & 4 \\
\hline 5 & Information \& Analysis & 6 & 5 \\
\hline 6 & Strategic planning & 3 & 6 \\
\hline 7 & Vision & 1 & 7 \\
\hline 8 & Program design & 1 & 7 \\
\hline 9 & Organizational culture & 1 & 7 \\
\hline 10 & Green product & 1 & 7 \\
\hline 11 & Technology management & 1 & 7 \\
\hline 12 & Employee involvement \& encouragement & 1 & 7 \\
\hline 13 & Benchmarking & 1 & 7 \\
\hline 14 & Organizational practices & 1 & 7 \\
\hline
\end{tabular}

\section{Methodology and Measurements}

The research design involves surveying using questionnaires. According to King, Keohane, and Verba (1994), researchers agree that quantitative research describes the quantity and tests relationships between variables at much greater precision than do most qualitative research. The data collected at a particular point in time, in period July 2017 to October 2017. A simple random sampling technique was adopted to select the respondents of study, the target sector is lecturers in Iraqi universities. Dependent on sample size recommendation in PLS-SEM for statistical power of $80 \%$ for the maximum number of six arrows that highlighted in this study is 130 respondents in freedom degree 95\% (Hair Jr, Hult, Ringle, \& 
Sarstedt, 2016). However, the last real respondents included 174 respondents. From another side, to measure the variables, a six-point Likert scale ranging from $1=$ strongly disagree to $6=$ strongly agree. It was adopted to measure the extent to which respondents agree or disagree with each of the statements in the questionnaire (Sriram, 2014). The independent variables using seven dimensions Top management commitment, Human resource development, customer focus, Management of process, quality Information and analysis, and Strategic planning of twenty-nine items. While the dependent variable, higher education excellence was also measured by 15 items.

\section{Data analysis and results}

There are major reasons to use PLS-SEM analysis to test the research model. According to Chin, Marcolin, and Newsted (2003) PLS-SEM able to assessing the theoretical structure model and measuring model at the same time. The second reason, PLS analysis is a component-based approach, as well as, There are no strict requirements for the selection of sample size, with the same pattern residual distribution (Lohmöller, 2013). Thirdly, PLS provide more accurate estimates through account a measurement error to interaction effects such as moderating variable (Chin et al., 2003). This research assesses the measurement model and the structural model (Hair, Hult, Ringle, \& Sarstedt, 2014; Vinzi, Chin, Henseler, \& Wang, 2010).

\section{Measurement model}

The original study model included 44 reflective measurement items (indicator or manifest variable) for six latent variables including 29 items for CSFs, and 19 items for higher education excellence. The reliability used as a tool to measurement models through measuring instrument measures whatever the concept that measuring, in addition, Validity is a test to measure how the instrument developed, it is intended to measuring the particular concept (Sekaran \& Bougie, 2010). In general, in order to assess the reflective measurement items, this study follow Hair, Sarstedt, Ringle, and Mena (2012). The convergent and discriminant validities were assessed followed by reliability analysis.

\section{Convergent validity}

According to Hair et al. (2014), convergent validity involves three main aspects namely, factor loadings, composite reliability (CR), and average variance extracted (AVE). The first aspect to achieve the convergent validity through examine the loading for all the items, the literature suggested the acceptable level for the items more than 0.50 in the multivariate analysis (Hair et al., 2014). Table 3 presents that all the factors loading significantly.

The second test is the composite reliability (CR). This test indicates the degree to which a set of items consistently indicate the latent construct (Hair et al., 2014). Table 3 show CR values ranged from 0.925 to 0.964 which overrides the recommended value of 0.70 .

Table 3: Convergent Validity Analysis

\begin{tabular}{|l|l|l|l|l|}
\hline Variables & Dimension & Code & CR & AVE \\
\hline Higher Education Excellence & & HEE & 0.956 & 0.774 \\
\hline CSFs & Top Management Commitment & TMC & 0.944 & 0.771 \\
\cline { 2 - 5 } & Human Resource Development & HRD & 0.945 & 0.774 \\
\cline { 2 - 5 } & Customer Focus & CF & 0.953 & 0.804 \\
\cline { 2 - 5 } & Management of Process & MP & 0.957 & 0.818 \\
\cline { 2 - 5 } & Quality Information and Analysis & QIA & 0.951 & 0.796 \\
\cline { 2 - 5 } & Strategic Planning & SP & 0.941 & 0.763 \\
\hline
\end{tabular}

The values of the average variance extracted (AVE) is the last examination to establish the convergent validity. Several scholars suggested that the AVE value more than 0.50 (Hair, Black, Babin, \& Anderson, 2010). In this research, all the constructs performing a good level of the construct validity of the measures used, as shown in Table 3, the AVE values up to 0.50 where it is valued ranged from 0.771 to 0.818. In addition to that, all the factors' loadings are significant at level 0.05 .

\section{Discriminant validity}

Discriminant validity of the measures is necessary to confirm the degree of measure distinct the concepts or items differentiates among constructs. Where it is compulsory prior to testing the hypotheses 
through the path analysis. This study examined the square root of AVE with the correlations among constructs. Ideally, its value should be up to 0.50 . In other words, $50 \%$ or more variance of the items should be accounted for. As illustrated, the square root of AVE for all the constructs in Table 4, the correlation matrix was placed on the diagonal elements. Where it is higher than the other element of the row and column in which they are located, this confirms the discriminant validity of the outer model. However, the result of all items shows significant value depending on the square root of AVE, their values ranged from 0.873 to 0.904 . These results obtained pertaining to the hypothesis testing should be valid and reliable.

Table 4: Discriminant Validity Analysis

\begin{tabular}{llllllll}
\hline CF & CF & HEE & HRD & MP & QIA & SP & TMC \\
HEE & 0.897 & & & & & & \\
HRD & 0.804 & 0.880 & & & & & \\
MP & 0.841 & 0.825 & 0.880 & & & & \\
QIA & 0.825 & 0.873 & 0.833 & 0.904 & & & \\
SP & 0.868 & 0.881 & 0.848 & 0.924 & 0.892 & & \\
TMC & 0.756 & 0.851 & 0.831 & 0.904 & 0.914 & 0.873 & \\
\hline
\end{tabular}

\section{The structural model}

This assessment depended on requirements that mentioned by Hair, Sarstedt, Hopkins, and Kuppelwieser (2014) considering the $\mathrm{R}^{2}$ values to assessed the variance explained in the outcome variable, by the predictor variables.

\section{Coefficient of determination $\left(\mathbf{R}^{2}\right)$}

The quality of the structural model assessing by the $\mathrm{R}^{2}$ value of endogenous latent variables. Where it is one of the most commonly used criteria for assessing structural model. The judgment of what $\mathrm{R}^{2}$ level is high depends, however, on the specific research discipline. During the assessment of the measurement model for this research, the standard PLS algorithm was calculated for the main effect model. The $\mathrm{R}^{2}$ value is 0.837 , based on the results of the path model reported in figure 1 .

The factors that selected to represent critical success factors of quality contribute 83.7 percent of the variance in higher education excellence. The remaining 14 percent was explained by other variables out of the scope of this research. Therefore, the value of $\mathrm{R} 2$ indicates that the power of the latent variables is described as substantial in explaining the higher education excellence.

\section{Hypothesis test}

The final step tests the hypothesized relationships, PLS-SEM testing it by a run algorithm and bootstrapping algorithm. In the PLS analysis, the path coefficients are very important, According to Hair et al. (2014) path significant show, the hypothesized direction support the proposed causal relationship empirically. On the other hand, the hypothesis should be rejected when the path is revealed signs that are against the hypothesized or direction non-significant.

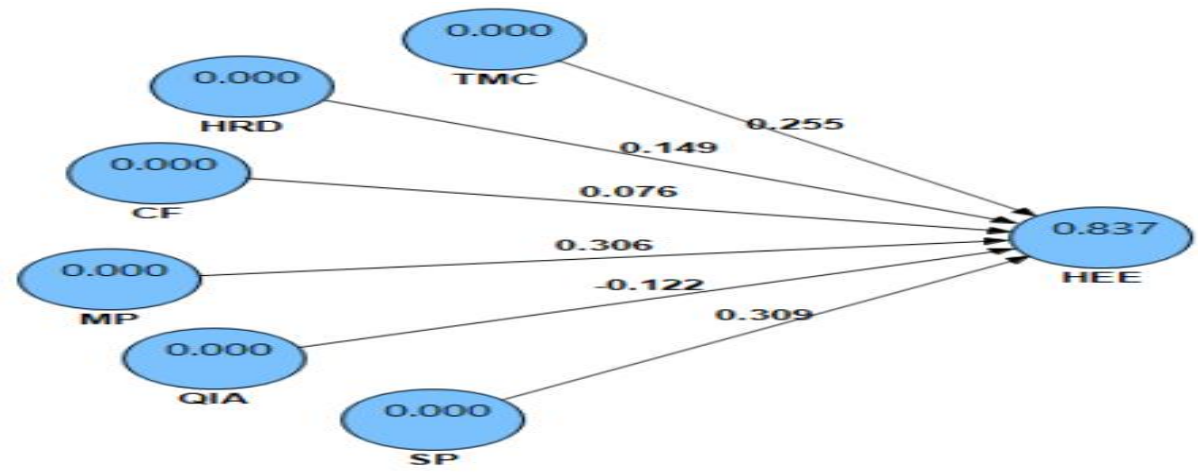

Figure 1: Research model 
There are six sub-hypotheses in this paper. Statistical T-values are substantially different from zero, it is largely defending on the degree of freedom, confidence interval, and directionality of hypothesis. Therefore, use P-value to ascertain if the paths are significant (Hair et al., 2014). In order to obtain the statistical T-values and the standard error, the PLS bootstrapping was run bootstrapping with 500 bootstrap samples which are bigger than the actual sample size of this study, thus meeting the condition suggested by Hair et al. (2013). The bootstrapping sample is considered adequate (Vinzi et al., 2010).

Table 5: The Results of the Inner Structural Model

\begin{tabular}{|l|l|l|l|l|l|l|}
\hline Hypothesis & $\begin{array}{l}\text { Hypothesized } \\
\text { Effect }\end{array}$ & $\begin{array}{l}\text { Path } \\
\text { coefficient }\end{array}$ & $\begin{array}{l}\text { Std. } \\
\text { Error }\end{array}$ & T Value & P Value & Decision \\
\hline H1.1 & TMC $\rightarrow$ HEE & 0.225 & 0.069 & $3.706^{* *}$ & 0.000 & Supported \\
\hline H1.2 & HRD $\rightarrow$ HEE & 0.149 & 0.064 & $2.350^{*}$ & 0.020 & Supported \\
\hline H1.3 & CF $\rightarrow$ HEE & 0.076 & 0.076 & 1.002 & 0.318 & Not Supported \\
\hline H1.4 & MP $\rightarrow$ HEE & 0.306 & 0.093 & $3.278^{* *}$ & 0.001 & Supported \\
\hline H1.5 & QIA $\rightarrow$ HEE & -0.122 & 0.102 & 1.193 & 0.235 & Not Supported \\
\hline H1.6 & SP $\rightarrow$ HEE & 0.309 & 0.113 & $2.735^{* *}$ & 0.007 & Supported \\
\hline
\end{tabular}

The results of the structural model (inner model) shown in Table 5. As it can be seen in hypothesis H1.1 stating there are direct effects of top management commitment on higher education excellence is supported at 0.01 level of significance $(\beta=0.225, \mathrm{~T}=3.706, \mathrm{P}<0.000)$. Thereafter, second sub-hypothesis H1.2 was also seen to be supported indicating there are direct effects of human resource development on higher education excellence at level $0.05(\beta=0.149, \mathrm{~T}=2.350, \mathrm{P}=0.020)$. While, third sub-hypothesis (H1.3) not support the direct relationship between customer focus on higher education excellence at level 0.01 $(\beta=0.076, T=1.002, P=0.318)$. Fourth sub-hypothesis (H1.4) support the direct relationship between management of process on higher education excellence at level $0.01(\beta=0.306, T=3.278, P=0.001)$. Also, fifth sub-hypothesis (H1.5) is not supported the direct relationship between quality information \& analysis and higher education excellence at level $0.01 \quad(\beta=-0.112, \mathrm{~T}=1.193, \mathrm{P}=0.235)$. Finally, the sixth sub-hypothesis supported the relationship between strategic planning and higher education excellence at level 0.01 $(\beta=0.182$, $\mathrm{T}=2.735, \mathrm{P}=0.007)$.

\section{Discussion and Implications}

The major aim of this paper to achieve the objective and question to investigate the relationship between CSFs and higher education excellence in Iraq. The result of the first sub-hypothesis (H1.1) supported direct effects of top management commitment on higher education excellence at 0.01 level of significance (Path Coefficient $=0.225, \mathrm{~T}=3.706, \mathrm{p}<0.000$ ) in level 0.01 . This empirical result corresponds with the previous authors' findings that argue top management commitment has influences on higher education excellence (Arnold \& Sangrà, 2018; Ekman, Lindgren, \& Packendorff, 2018). This factor contained several items that built this construct. The most plausible reason for getting a positive result, it was attributed to the fact that the vision of the top management was focused on quality improvement. Consequently, top management provides personal leadership for quality improvement. It achieves this by pursuing its quality objective in the long term.

The second sub-hypothesis is designed to determine the relationship between human resource developments on higher education excellence. However, H1.2 hypothesized that the direct effects of human resource development on higher education excellence, and it is postulated the relationship to be significant. In this paper, the result of the second hypothesis supported. There are studies support the direct relationship between human resource development and excellence (Stock et al., 2007; Stough, Ceulemans, Lambrechts, \& Cappuyns, 2018). The human source development in Iraqi HEIs revealed that the highest performing staff can be involved in the process of quality improvement. Their performance is providing courses that contribute to the development of the capacities of the lecturers and administrative staff in the field of quality management. In addition to rewarding employees for their efforts in the field of quality, teams were also established with the aim of solving problems.

Unfortunately, the results showed that the relationship of the third sub-hypothesis which states direct effects of customer focus on higher education excellence is not supported at level 0.01 (Path Coefficient $=0.076, \mathrm{~T}=1.002, \mathrm{P}=0.318$ ), this result came in line with Basu, Bhola, Ghosh, and Dan (2016) 
study. this result may be due to lack of clarity of the role of customer in Iraqi universities, the reason for this is limited to identify and how to deal with customers who are not only students, but there are studies indicated to other categories representing the customers in universities such as parents, employee, alumni, and stakeholders.

As well as, the relationship between management of process and higher education excellence that mentions in the fourth hypothesis was supported, which came in line with previous studies such as (Laosirihongthong, Teh, \& Adebanjo, 2013; Martin \& Thawabieh, 2018). The management of process in Iraqi universities revealed that the most plausible reason for the high level of it may be due to the fact that the top management carefully considered factors such as quality, productivity, cost, and new technology during a design process. In addition to the fact that the process of the university has continuously improved and they evaluate services on the basis of efficiency.

The fifth sub-hypothesis also rejected at level 0.01 (Path Coefficient $=-0.122, \mathrm{~T}=1.193, \mathrm{P}=0.235$ ), that states direct effects of quality Information and analysis on higher education excellence, the reject may be due to lack of important information and there is a limitation of use quality tools to get information that leads to improving quality.

The sixth sub-hypothesis is designed to determine the relationship between strategic planning on higher education excellence. However, H1.6 hypothesized that direct effects of strategic planning for higher education excellence, and it is postulated the relationship to be significant. In this paper, the result of the second hypothesis supported in level 0.01 (Path Coefficient $=0.309, \mathrm{~T}=2.735, \mathrm{P}=0.007$ ). There are studies support the direct relationship between strategic planning in higher education (Bryson, 2015; Cruz, 2018; Martin \& Thawabieh, 2018). These studies have the distinction of being presented to measure the results of the direct relationship between the strategic planning and non-financial performance. This paper revealed that Strategic planning was converted into real actions, and that resource allocation depended on the strategic objectives that support quality improvement in the long-term.

The results of allowing for support relationship between crucial success factors and higher education excellence that could be engaged by Iraqi universities, in order to enhance their performance to reach the excellence. Another leading implication of this study that relevant to the universities in Iraq to evaluate the model which incorporates the components of CSFs to excellence. Specifically, this paper affirms the formation of empirical relationships between this variable. Finally, this research recommends to the researchers in the future to expand the extent of realizing the concept of excellence in universities, by exploring and testing other possible factors that could affect excellence, especially in the service field.

\section{The limitations and scope for the future studies}

The study discussed the higher education sector in Iraq (the government sector), where the study of a range of variables most reliable in previous studies, where it is recommended to study other variables as future studies. Furthermore, it is recommended to test the study variables in private universities.

\section{References}

Ahmad, H., Francis, A., \& Zairi, M. (2007). Business process reengineering: critical success factors in higher education. Business Process Management Journal, 13(3), 451-469.

Antony, J., Leung, K., Knowles, G., \& Gosh, S. (2002). Critical success factors of TQM implementation in Hong Kong industries. International Journal of Quality \& Reliability Management, 19(5), 551-566.

Arnold, D., \& Sangrà, A. (2018). Dawn or dusk of the 5 th age of research in educational technology? A literature review on (e-) leadership for technology-enhanced learning in higher education (2013-2017). International Journal of Educational Technology in Higher Education, 15(1), 24.

Awheda, A., Ab Rahman, M. N., Ramli, R., \& Arshad, H. (2016). Factors related to supply chain network members in SMEs. Journal of Manufacturing Technology Management, 27(2), 312-335.

Badri, Abdulla, M., Selim, H., Alshare, K., Grandon, E. E., Younis, H., \& Abdulla, M. (2006). The Baldrige Education Criteria for performance excellence framework: Empirical test and validation. International Journal of Quality $\mathcal{E}$ Reliability Management, 23(9), 1118-1157.

Basu, R., Bhola, P., Ghosh, I., \& Dan, P. K. (2016). Critical linkages between quality management practices and performance from Indian IT enabled service SMEs. Total Quality Management $\mathcal{E}$ Business Excellence, 1-39.

Bryson, J. M. (2015). Strategic planning for public and nonprofit organizations. International Encyclopedia of the Social $\mathcal{E}$ Behavioral Sciences, 23. 
Chan, F., Lau, H., Ip, R., Chan, H., \& Kong, S. (2005). Implementation of total productive maintenance: A case study. International journal of production economics, 95(1), 71-94.

Chin, W. W., Marcolin, B. L., \& Newsted, P. R. (2003). A partial least squares latent variable modeling approach for measuring interaction effects: Results from a Monte Carlo simulation study and an electronic-mail emotion/adoption study. Information systems research, 14(2), 189-217.

Chuang, S.-P., \& Yang, C.-L. (2014). Key success factors when implementing a green-manufacturing system. Production Planning \& Control, 25(11), 923-937.

Cruz, L. R. (2018). Determining how work process influences organizational results using the Malcolm Baldrige Excellence Framework. Creighton University.

Daniel, D. R. (1961). Management information crisis. Harvard business review, 39(5), 111-121.

Ekman, M., Lindgren, M., \& Packendorff, J. (2018). Universities need leadership, academics need management: discursive tensions and voids in the deregulation of Swedish higher education legislation. Higher Education, 75(2), 299-321.

Farris, J. A., Van Aken, E. M., Doolen, T. L., \& Worley, J. (2009). Critical success factors for human resource outcomes in Kaizen events: An empirical study. International journal of production economics, 117(1), 42-65.

Glover, W. J., Farris, J. A., Van Aken, E. M., \& Doolen, T. L. (2011). Critical success factors for the sustainability of Kaizen event human resource outcomes: An empirical study. International journal of production economics, 132(2), 197-213.

Hair, J. F., Black, W., Babin, B. J., \& Anderson, R. E. (2010). Multivariate data analysis: A global perspective: Upper Saddle River: Pearson Education.

Hair, J. F., Hult, G. T. M., Ringle, C., \& Sarstedt, M. (2014). A Primer on partial least squares structural equation modeling (PLS-SEM): SAGE Publications Asia-Pacific Pte. Ltd.

Hair , J. F., Sarstedt, M., Hopkins, L., \& Kuppelwieser, V. G. (2014). Partial least squares structural equation modeling (PLS-SEM) An emerging tool in business research. European Business Review, 26(2), 106-121.

Hair, J. F., Sarstedt, M., Ringle, C. M., \& Mena, J. A. (2012). An assessment of the use of partial least squares structural equation modeling in marketing research. Journal of the Academy of Marketing Science, 40(3), 414-433.

Hair Jr, J. F., Hult, G. T. M., Ringle, C., \& Sarstedt, M. (2016). A primer on partial least squares structural equation modeling (PLS-SEM): Sage Publications.

Honnutagi, A. R., Sonar, R., \& Babu, S. (2011). Criterion Weights for Knowledge Management Integrated Quality Accreditation System for Indian Engineering Education Using Analytical Hierarchy Process. World, 1(5), 159174.

Hussain, K., \& Birol, C. (2011). The assessment of non-academic and academic service quality in higher education. Egitim Arastirmalari-Eurasian Journal of Educational Research, 1(42), 95-116.

Islam, R. (2007). MBNQA criteria in education: assigning weights from a Malaysian perspective and proposition for an alternative evaluation scheme. International transactions in operational research, 14(5), 373-394.

King, G., Keohane, R. O., \& Verba, S. (1994). Designing social inquiry: Scientific inference in qualitative research: Princeton University Press.

Koo, C., Chung, N., \& Ryoo, S. Y. (2014). How does ecological responsibility affect manufacturing firms' environmental and economic performance? Total Quality Management \& Business Excellence, 25(9-10), 1171-1189.

Laosirihongthong, T., Teh, P.-L., \& Adebanjo, D. (2013). Revisiting quality management and performance. Industrial Management \& Data Systems, 113(7), 990-1006.

Lohmöller, J.-B. (2013). Latent variable path modeling with partial least squares: Springer Science \& Business Media.

Martin, A., \& Thawabieh, F. A. (2018). The Effect of ISO 9001 to Oman Higher Education Operational Performance: Buraimi University College as a Case Study. International Journal of Applied Engineering Research, 13(6), 39393947.

Mishra, R., Pundir, A. K., \& Ganapathy, L. (2016). Conceptualizing sources, key concerns and critical factors for manufacturing flexibility adoption: an exploratory study in Indian manufacturing firms. Journal of Manufacturing Technology Management, 27(3), 379-407.

Policy, N. C. f. P., \& Education, H. (2000). Measuring up 2000: the state-by-state report card for higher education: National Center for Public Policy and Higher Education.

Sekaran, U., \& Bougie, R. (2010). Research methods for business: A skill building approach. Wiley: London.

Seth, D., Seth, D., Shrivastava, R., Shrivastava, R., Shrivastava, S., \& Shrivastava, S. (2016). An empirical investigation of critical success factors and performance measures for green manufacturing in cement industry. Journal of Manufacturing Technology Management, 27(8), 1076-1101.

Shieh, J.-I., Wu, H.-H., \& Huang, K.-K. (2010). A DEMATEL method in identifying key success factors of hospital service quality. Knowledge-Based Systems, 23(3), 277-282.

Sondari, M. C. (2013). Examining Job Description to Develop Job Performance Indicators for Higher Education Institution Based on MBNQA Education Criteria. Journal of Education \& Vocational Research, 4(4). 
Sriram, R. (2014). Five things not to do in developing surveys for assessment in student affairs. NASPA Research and Policy Institute Brief, 1-11.

Stock, G. N., McFadden, K. L., \& Gowen, C. R. (2007). Organizational culture, critical success factors, and the reduction of hospital errors. International journal of production economics, 106(2), 368-392.

Stough, T., Ceulemans, K., Lambrechts, W., \& Cappuyns, V. (2018). Assessing sustainability in higher education curricula: a critical reflection on validity issues. Journal of Cleaner Production, 172, 4456-4466.

Talib, F., \& Rahman, Z. (2010). Critical success factors of TQM in service organizations: a proposed model. Services Marketing Quarterly, 31(3), 363-380.

UNESCO. (2013). Generalizing Quality assurance in Higher Education in Iraq. UNESCO Office for Iraq Retrieved from http://www.unesco.org/new/en/iraq-office/about-this-office/singleview/news/generalizing_quality_assurance_in_higher_education_in_iraq/.

Vinzi, V. E., Chin, W. W., Henseler, J., \& Wang, H. (2010). Handbook of partial least squares: Concepts, methods and applications: Springer.

Yeoh, W., \& Koronios, A. (2010). Critical success factors for business intelligence systems. Journal of computer information systems, 50(3), 23-32. 